\title{
Improvement of primary biliary cholangitis (PBC) under treatment with sulfasalazine and abatacept
}

\author{
Florian Popp, ${ }^{1}$ David Semela, ${ }^{2}$ Johannes von Kempis, ${ }^{1}$ Ruediger B Mueller ${ }^{1}$
}

'Division of Rheumatology, Immunology and Rehabilitation, Kantonsspital Sankt Gallen, Sankt Gallen, Switzerland ${ }^{2}$ Division of Gastroenterology and Hepatology, Kantonsspital Sankt Gallen, Sankt Gallen, Switzerland

Correspondence to Dr Florian Popp, florian.popp@kssg.ch

Accepted 26 April 2018
To cite: Popp F, Semela D, von Kempis J, et al. BMJ Case Rep Published Online First: [please include Day Month Year]. doi:10.1136/bcr-2018224205

\section{DESCRIPTION}

A 51-year-old female patient was diagnosed with primary biliary cholangitis (PBC) in 2012 and rheumafactor-positive, Anti-citrullinated protein antibodies (ACPA)-positive rheumatoid arthritis (RA) in 2013. The diagnosis of a PBC was confirmed by liver biopsy showing portal inflammatory infiltrates with non-suppurative inflammatory lesions of the biliary duct (figure 1). PBC has been treated with ursodeoxycholic acid since 2012.

After diagnosis of RA (initial Disease Activity Score 28 (DAS 28) $=6.43$ ), therapy was initiated with leflunomide $20 \mathrm{mg} /$ day and low-dose oral glucocorticoids, tapered from $20 \mathrm{mg} /$ day to zero over 12 weeks. Remission was reached within 4 months (DAS $28=1.84$ ). However, elevated transaminases were detected. As a consequence, leflunomide was switched to sulfasalazine in September 2013. After an increase of activity of RA under sulfasalazine, abatacept $750 \mathrm{mg}$ every 4 weeks was added to treatment in January 2015. Under this treatment strategy remission was achieved in April 2015 and maintained thereafter (September 2017, DAS 28=2.27).

Liver stiffness as surrogate for fibrosis/cirrhosis was determined by elastography. It improved and normalised under treatment with sulfasalazine and abatacept $(6.0 \mathrm{kPa}$ in September 2013, $3.9 \mathrm{kPa}$ in December 2016). Alkaline phosphatase and gamma-glutamyltransferase were elevated up to four times over the norm upon diagnosis of PBC. These enzymes showed, apart from transient elevation while leflunomide treatment, continuous improvement and finally normalised under treatment with abatacept and sulfasalazine (November 2017). In a control liver biopsy in September 2017 findings were improved, showing histologically only discrete portal and lobar inflammation without the typical pattern of a PBC (figure 2).

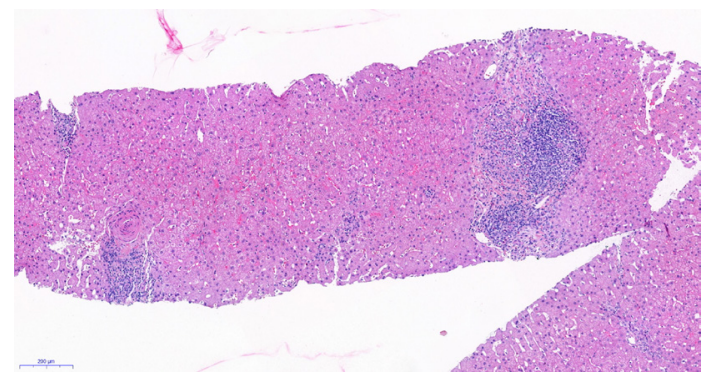

Figure 1 Dense lymphocytic infiltrates in portal tracts affecting small portal bile ducts, moderate lobular infiltrates.

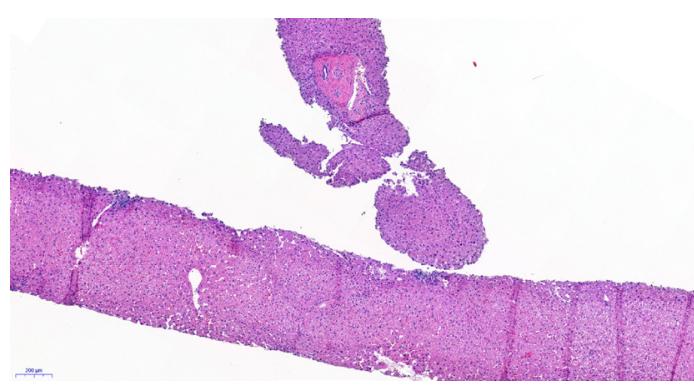

Figure 2 Regredient lymphocytic infiltrates, focal portal and periductal fibrosis without inflammation, preserved lobular architecture.

\section{Patient's perspective}

The diagnosis of PBC in 2012 and RA in 2013 was hard to cope with, especially when the side effects of leflunomide appeared and the sulfasalazine monotherapy did not show the wanted effect. Besides the knowledge of having an autoimmune disease of the liver, the everyday restriction caused by the temporary active RA was, apart from the need for oral glucocorticoids, which I was focused on in a negative way. With the well-tolerated, new treatment combination (sulfasalazine and abatacept), both diseases, PBC and RA, are fortunately in remission, which makes me look positively into my future.

\section{Learning points}

T cells play an important role in the pathogenesis of autoimmune diseases like primary biliary cholangitis (PBC) and rheumatoid arthritis.

- Abatacept can be a significant treatment option in T cell-mediated diseases-further studies need to be made, especially for diseases like $\mathrm{PBC}$, in which abatacept is not a recognised standard treatment.

This case demonstrates improvement of $\mathrm{PBC}$ under therapy for RA with sulfasalazine and abatacept. The decision to use abatacept was supported by findings demonstrating participation of $\mathrm{T}$ cells in the pathogenesis of $\mathrm{PBC}^{1}$ and by Dhirapong et $a l^{2}$ who reported positive effects of therapy with abatacept in a mouse model for PBC.

Contributors FP and RBM: interpretation of data, writing of the manuscript, therapeutic decisions and monitoring of patient. DS: interpretation of data, writing of the manuscript, fibroscan and liver biopsy. JvK: interpretation of data and writing of the manuscript. 


\section{Images in...}

Funding The authors have not declared a specific grant for this research from any funding agency in the public, commercial or not-for-profit sectors.

Competing interests None declared.

\section{Patient consent Obtained.}

Provenance and peer review Not commissioned; externally peer reviewed.

(C) BMJ Publishing Group Ltd (unless otherwise stated in the text of the article) 2018. All rights reserved. No commercial use is permitted unless otherwise expressly granted.

\section{REFERENCES}

1 Yang GX, Wu Y, Tsukamoto $\mathrm{H}$, et al. CD8 T cells mediate direct biliary ductule damage in nonobese diabetic autoimmune biliary disease. J Immunol 2011;186:1259-67.

2 Dhirapong A, Yang GX, Nadler S, et al. Therapeutic effect of cytotoxic T lymphocyte antigen $4 /$ immunoglobulin on a murine model of primary biliary cirrhosis. Hepatology 2013;57:708-15.

Copyright 2018 BMJ Publishing Group. All rights reserved. For permission to reuse any of this content visit http://group.bmj.com/group/rights-licensing/permissions.

BMJ Case Report Fellows may re-use this article for personal use and teaching without any further permission.

Become a Fellow of BMJ Case Reports today and you can:

- Submit as many cases as you like

- Enjoy fast sympathetic peer review and rapid publication of accepted articles

- Access all the published articles

Re-use any of the published material for personal use and teaching without further permission

For information on Institutional Fellowships contact consortiasales@bmjgroup.com

Visit casereports.bmj.com for more articles like this and to become a Fellow 